\title{
Chapter 2 - The Dangers of Complacency: The Case for Reforming Fiscal Policy in Australia
}

\section{Bob McMullan MP}

\section{Lecture presented 27 April 2005}

Australia entered the $20^{\text {th }}$ century as arguably the richest country in the world. However, during the century we slowly fell through the rankings. This was not primarily because we went backwards, but rather that we failed to keep pace with our competitors. We face a similar challenge as we enter the $21^{\text {st }}$ century. We do not enter this century as the richest country in the world, but we are one of the fastest-growing developed economies. However, there are signs that the same factors which led to our decline last century are re-emerging. Therefore, it is timely to examine what caused our genteel decline and the factors which underpinned our improved performance over the last 20 years so that we may apply those lessons to our $21^{\text {st }}$ century challenges.

A brief examination of the statistical evidence illustrates the extent and significance of Australia's underperformance during the $20^{\text {th }}$ century. Consideration of this illustrates the potential consequences should a similar loss of momentum continue through the early $21^{\text {st }}$ century.

Paul Ormerod, in Butterfly Economics, cites Australia as one of those at the bottom of the league table of Western economies in terms of growth performance during the $20^{\text {th }}$ century. He estimates we were one of only three which grew at less than 1.5 percent on average over the period. Ormerod also cites Australia in the early part of the $20^{\text {th }}$ century as one of the few countries to achieve higher per capita GDP than the US during this period. And yet we had fallen to 76 per cent of US per capita GDP in the early 1970s; to 70 per cent by 1990 and had recovered only to the 1970s level by 2002 (OECD Economic Survey of Australia, February 2005:30). Put simply, this means the average Australian is thousands of dollars per year worse off than they should have been. It also means we as a nation have fewer resources to apply to the social and national challenges we face today.

America's economic performance has been strong and steady. While the average increase in real per capita income in the US over the century to 1997 appears modest - slightly below 2 per cent - the cumulative effect has been dramatic as the graph in Figure 1 illustrates: 
Figure 1 - Real per capita income in US dollars 1870-1997

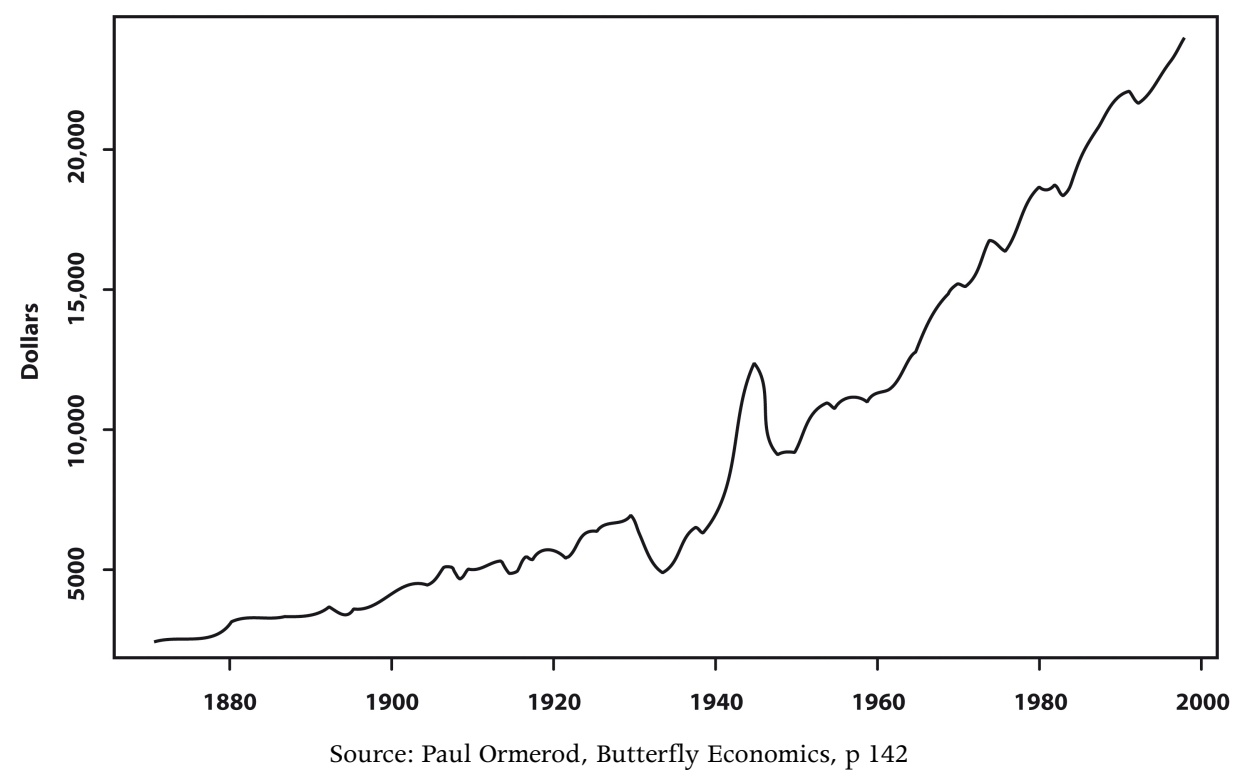

The comparative rate of growth between Australia and the US, as shown in Figure 2 below, graph based on data for the USA and Australia illustrates the compounding impact of the gap between our respective performances over the previous century.

Figure 2 - Australia and United States GDP Growth per Capita 1900-2000

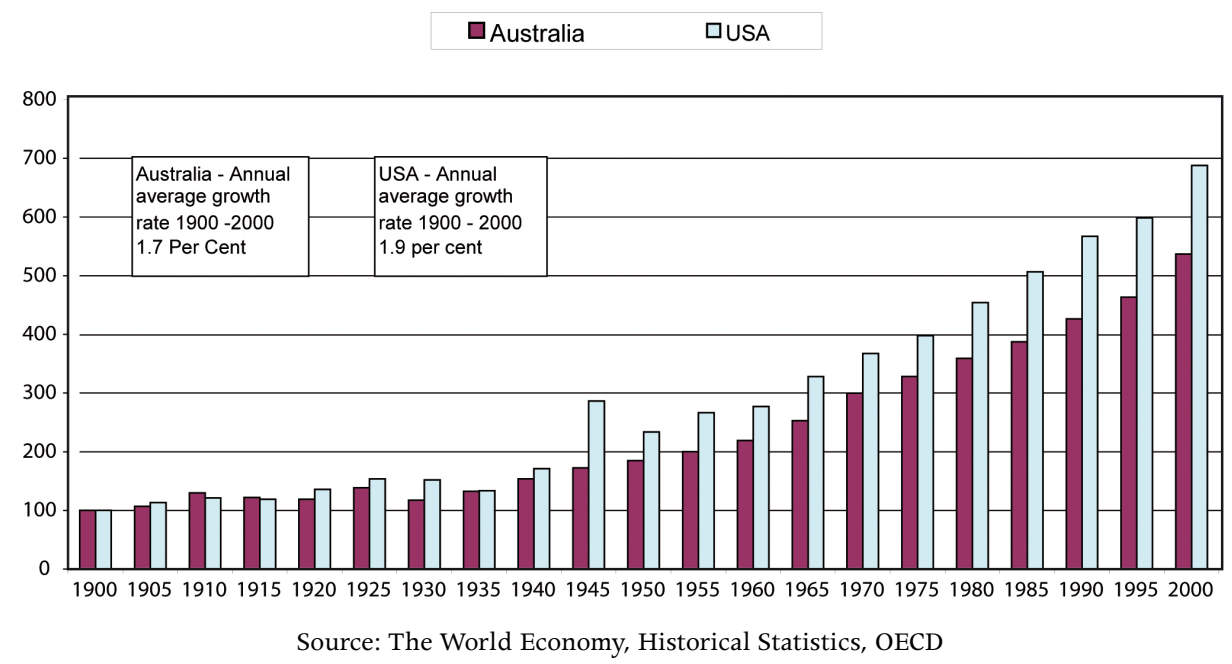

The implications of this long-term analysis are reinforced by Tiffen and Gittins in their excellent book, How Australia Compares. This provides a number of tables which throw an interesting light on Australia's economic performance 
over the last century. They quote work by Angus Maddison which estimates world economic growth over the last century. Table 1 below refers to income per capita over the period 1870 to 1998 :

\section{Table 1}

\begin{tabular}{|c|c|c|c|c|c|}
\hline \multicolumn{6}{|c|}{ Income per capita, 1870-1998 } \\
\hline & \multicolumn{5}{|c|}{ Per capita income in 000s of 1990 international dollars } \\
\hline & 1870 & 1913 & 1950 & 1973 & 1998 \\
\hline United States & 2.4 & 5.3 & 9.6 & 16.7 & 27.3 \\
\hline Norway & 1.4 & 2.5 & 5.4 & 11.2 & 23.7 \\
\hline Denmark & 2.0 & 3.9 & 6.9 & 14.0 & 22.1 \\
\hline Switzerland & 2.2 & 4.3 & 9.1 & 18.2 & 21.4 \\
\hline Canada & 1.7 & 4.4 & 7.4 & 13.8 & 20.6 \\
\hline Japan & 0.7 & 1.4 & 1.9 & 11.4 & 20.4 \\
\hline Australia & 3.6 & 5.7 & 7.5 & 12.8 & 20.4 \\
\hline Netherlands & 2.8 & 4.0 & 6.0 & 13.1 & 20.2 \\
\hline France & 1.9 & 3.5 & 5.3 & 13.1 & 19.6 \\
\hline Belgium & 2.7 & 4.2 & 5.6 & 12.2 & 19.4 \\
\hline Austria & 1.9 & 3.5 & 3.7 & 11.2 & 18.9 \\
\hline United Kingdom & 3.2 & 4.9 & 6.9 & 12.0 & 18.7 \\
\hline Sweden & 1.7 & 3.1 & 6.7 & 13.5 & 18.7 \\
\hline Finland & 1.1 & 2.1 & 4.3 & 11.1 & 18.3 \\
\hline Ireland & - & - & 3.4 & 6.9 & 18.2 \\
\hline Germany & 1.8 & 3.6 & 3.9 & 12 & 17.8 \\
\hline Italy & 1.5 & 2.6 & 3.5 & 10.6 & 17.8 \\
\hline New Zealand & 2.7 & 5.2 & 8.5 & 12.5 & 14.8 \\
\hline Mean & 2.1 & 3.8 & 5.9 & 12.6 & 19.9 \\
\hline
\end{tabular}

Source: Rodney Tiffen \& Ross Gittins, How Australia Compares: 42

In 1870 and 1913 Australia was at the top of the table for per capita income. However, by 1950 we had dropped to fourth and by 1973 we were no better than eighth. The period from 1973 to 1998 has seen us improve to sixth.

The comparative figures on the fastest growing economies (Table 2 below) provide a dramatic demonstration of Australia's poor relative performance in the early part of the $20^{\text {th }}$ century. Of the 17 countries measured, from 1822 to 1870 Australia was clearly the fastest growing economy in the world, yet from 1870 to 1913 Australia had fallen to $14^{\text {th }}$ position. In the period 1913 to 1950 we fell further to be the $15^{\text {th }}$ fastest growing economy. Significantly, the only countries with lower growth rates than Australia were Austria and Germany, which were reaping the consequences of the First World War. 
Table 2

\begin{tabular}{|c|c|c|c|c|c|}
\hline \multicolumn{6}{|c|}{ Economic growth, $1820-1998$ Average per capita growth rates, $\%$} \\
\hline & $1820-70$ & $1870-1913$ & $1913-50$ & $1950-73$ & $1973-98$ \\
\hline Ireland & - & - & - & 3.04 & 3.97 \\
\hline Norway & 0.52 & 1.3 & 2.13 & 3.19 & 3.02 \\
\hline Japan & 0.19 & 1.48 & 0.89 & 8.05 & 2.34 \\
\hline Austria & 0.85 & 1.45 & 0.18 & 4.94 & 2.1 \\
\hline Italy & 0.59 & 1.26 & 0.85 & 4.95 & 2.07 \\
\hline Finland & 0.76 & 1.44 & 1.91 & 4.25 & 2.03 \\
\hline United States & 1.34 & 1.82 & 1.61 & 2.45 & 1.99 \\
\hline Belgium & 1.44 & 1.05 & 0.7 & 3.55 & 1.89 \\
\hline Australia & 3.99 & 1.05 & 0.73 & 2.34 & 1.89 \\
\hline Denmark & 0.91 & 1.57 & 1.56 & 3.08 & 1.86 \\
\hline United Kingdom & 1.26 & 1.01 & 0.92 & 2.44 & 1.79 \\
\hline Netherlands & 0.83 & 0.9 & 1.07 & 3.45 & 1.76 \\
\hline France & 0.85 & 1.45 & 1.12 & 4.05 & 1.61 \\
\hline Germany & 1.09 & 1.63 & 0.17 & 5.02 & 1.6 \\
\hline Canada & 1.29 & 2.27 & 1.4 & 2.74 & 1.6 \\
\hline Sweden & 0.66 & 1.46 & 2.12 & 3.07 & 1.31 \\
\hline New Zealand & 3.9 & 1.51 & 1.35 & 1.72 & 0.67 \\
\hline Switzerland & 1.09 & 1.55 & 2.06 & 3.08 & 0.64 \\
\hline Mean & 1.27 & 1.42 & 1.22 & 3.63 & 1.9 \\
\hline
\end{tabular}

Source: Rodney Tiffen \& Ross Gittins, How Australia Compares: 44

However, the most telling part of the table is for the period 1950 to 1973, often paradoxically referred to as the 'golden years'. In this period, while Australia, like all other Western countries, was experiencing strong economic growth, our relative economic performance was dreadful. We fell to $17^{\text {th }}$ out of 18 and grew at less than two thirds the average rate of other developed countries. During the final period referred to by Tiffen and Gittins, from 1973 to 1998, Australia improved to eighth in the global economic race.

Table 3 below demonstrates the comparative trade performance of developed countries. Australia, like all the other developed countries, with the possible exception of Japan, has increased its trade intensity over the last 30 years. However our trade performance has been consistently poor. During the 1970s our net trade performance was about the middle of the field and better than average. However, during the 1980s and 1990s we crashed to almost the bottom of the list and remained there. It is impossible to see how Australia can succeed in the medium term without an improvement in this area. 
Table 3

\begin{tabular}{lrrrr}
\hline & Trade balance as \% of GDP, $1970-99$ & & \\
& & & & \\
Ireland & $1970-73$ & $1974-79$ & $1980-89$ & $1990-99$ \\
Norway & -7.4 & -11.3 & -2.5 & 9.9 \\
Netherlands & 0.6 & -2.7 & 4.1 & 6.3 \\
Finland & 0.2 & 1 & 3 & 5.1 \\
Denmark & -1.1 & -0.9 & 0.4 & 5 \\
Sweden & -1.5 & -2.8 & 1 & 4.8 \\
Switzerland & 1.4 & -0.5 & 1.5 & 4.6 \\
Belgium & -1.2 & 1.4 & -0.2 & 3.6 \\
Italy & 2.3 & -0.8 & 0.3 & 3.5 \\
Japan & -0.1 & -0.2 & -0.5 & 2.5 \\
New Zealand & 1.6 & 0.4 & 1.9 & 1.6 \\
Canada & 0.2 & -4 & -1 & 1.6 \\
France & 1.6 & -0.3 & 1.8 & 1.3 \\
Germany & 0.1 & -0.7 & -1.4 & 1.3 \\
Austria & 1.9 & 2.2 & 2.6 & 0.9 \\
Australia & 0.6 & -0.8 & 0.2 & -0.2 \\
United Kingdom & 0.9 & -0.5 & -2.2 & -0.9 \\
United States & -0.1 & -0.9 & -0.2 & -1 \\
& 0.1 & -0.4 & -1.8 & -1.2 \\
Mean & & & & \\
\hline Surc: Rod & 0 & -1.2 & 0.4 & 2.7 \\
\hline
\end{tabular}

Source: Rodney Tiffen \& Ross Gittins, How Australia Compares: 50

One aspect of our performance to which economists would give great weight in relation to overall current account problems is the relative net saving performance. Australia's performance is very poor over the period from 1970 to 1999. Absolute saving performance has fallen from 12.4 per cent of GDP to 2.2 per cent, and we have fallen decisively to last place on the global savings list. It is important to remember that this net savings effort is something to which government can contribute directly through its own budgetary efforts.

This is where the figures are somewhat surprising. While Australia's overall budget balance has improved significantly in recent years we have merely kept pace with the average performance of other countries. As the following table (Table 4) shows, Australia's performance in the budget balance has not improved since the small but significant relative improvement during the Hawke government. However, putting aside minor variations we have been in the middle of the field for the last 30 years. 
Table 4

Budget balance Mean budget surplus/deficit as \% of GDP during period of each government

\begin{tabular}{lrrrrrr} 
& McMahon & Whitlam & Fraser & Hawke & Keating & Howard \\
& $1970-72$ & $1973-75$ & $1976-82$ & $1983-91$ & $1992-95$ & $1996-2002$ \\
17-country mean & 0.4 & -1 & -3.2 & -2.9 & -4.7 & 0.1 \\
Australia & -0.3 & -2.4 & -3.8 & -3.1 & -4.5 & -0.1 \\
Australia's rank & 11 & 12 & 12 & 9 & 9 & 9 \\
Highest country & Sweden & Finland & Finland & Norway & Norway & Norway \\
Value & 4.7 & 5.1 & 4.6 & 4.5 & 0.2 & 9.2 \\
Lowest country & Italy & Italy & Ireland & Italy & Sweden & Japan \\
Value & -5.4 & -8.6 & -9.8 & -10.9 & -9.6 & -5.8 \\
\hline
\end{tabular}

Table 5 best illustrates the poor economic performance of the past and the risks of the present.

Table 5

\begin{tabular}{lrrrrrr}
\hline \multicolumn{7}{c}{ Economic growth Mean per capita GDP growth rates (\% per annum) during each government } \\
& McMahon & Whitlam & Fraser & Hawke & Keating & Howard \\
& $1971-72$ & $1973-75$ & $1976-82$ & $1983-91$ & $1992-95$ & $1996-2000$ \\
18-country mean & 3.2 & 2 & 1.9 & 2.2 & 1.6 & 2.8 \\
Australia & 1.6 & 1.7 & 1.1 & 1.9 & 3.1 & 3 \\
Australia's rank & 17 & 12 & 14 & 12 & 3 & 5 \\
Highest growth & Japan & Norway & Norway & Japan & Ireland & Ireland \\
Value & 5.2 & 3.8 & 3.2 & 3.7 & 4.8 & 8.8 \\
Lowest growth & Sweden & Switzerland & New Zealand New Zealand & Switzerland & Japan \\
Value & 1.1 & -1 & 0.2 & 0.1 & -0.8 & 1.1 \\
\hline
\end{tabular}

Source: Rodney Tiffen \& Ross Gittins, How Australia Compares: 92

Table 5 shows average per capita Gross Domestic Product (GDP) growth rates during the period of each recent Australian government. It demonstrates the very poor performance up to the 1980s and a significant improvement in later years. However, the period 1996 to 2000 does show the first signs of slippage. This is neither the place nor the time to enter contemporary controversy about the reasons for our recent economic improvement being at risk. Issues like skills, infrastructure and research and development are matters for robust debate in the day-to-day political contest.

My concern here is for the longer term. I attribute much of our relative decline during the early and mid $20^{\text {th }}$ century to an arrogant complacency that our resource endowments would guarantee us our place in the world without us having to make the hard decisions others might have to face. Indeed, Donald Horne captured this sentiment in his celebrated phrase 'The Lucky Country'. It took much debate and difficult reforms in the 1980s and 1990s to turn this around. The signs of such complacency are beginning to emerge again. Therefore I wish to concentrate in this presentation today on the issues relating to failings in the intellectual and administrative infrastructure which underpin the national economic debate. 
The experience of previous decades shows that the quality of economic analysis and debate in any one period is a significant factor in creating the preconditions for strong economic growth in the future. The history of reform in Australia, which bore fruit in the 1980s and 1990s, has its origin in the quality of the economic debate and analysis in earlier years. This claim is supported by the Organisation for Economic Co-operation and Development (OECD 2004: 8) in its most recent report, OECD Economic Surveys Australia 2004, which states, 'The Australian economy is still benefiting from the program of widespread and deep reforms that started in the 1980s'. Further it said, 'Australia became a model for other OECD countries ... (due to) ....the tenacity and thoroughness with which deep structural reforms were proposed, discussed, legislated, implemented and followed-up' (2004: 11). But also, and importantly for my argument here, 'The pace of reform has recently not been as strong as it could have been.' (2004: 11).

Much of the quality of that economic debate to which the OECD refers was enhanced by the independent (and sometimes fiercely independent) analysis by the Productivity Commission and its predecessors. John Warhurst, in Jobs or Dogma, outlines the history of the Tariff Board and its successor, the Industries Assistance Commission (IAC), and their struggle to change economic policy and debate in this country. He describes the quality of their contribution as, 'the advice given to the Government on the economic costs and benefits was recognised as one of the highest calibre which could reasonably be expected from the Australian economics profession. Therefore that advice ... was by and large supported by members of the profession in academia, government and the media.' (1982: 5).

He also recognised the importance of their activism: 'the IAC as an active participant pressing its own views both formally and informally' (1982: 3) and their long term perspective and educational function: 'The IAC always remained optimistic that short-term pressures on government policy making could be lessened ... by the provision of greater information about the future. It believed that ignorance of the future made governments vulnerable to ad hoc decisions.' (1982: 3). In support he quotes a 1978 IAC staff paper: 'if the community at large has no awareness of the problems, it will be less prepared to bear the short-term costs of possible solutions.' (1982: 232).

There is no more significant indication of the power and significance of the debates generated by these agencies than Gough Whitlam's famous phrase: 'I am a Rattigan man'. (Warhurst 1982: 3) With this phrase Whitlam was both confirming his commitment to lower tariffs and acknowledging the lead role which the Tariff Board and its then Chairman had played in that debate. Over the next 30 years the Industries Assistance Commission, the Industries Commission and the Productivity Commission have played a major advocacy 
and educative role which has helped the overall economic reform process significantly.

The key question today is: Is the commitment to reform faltering?

It has been significant that, we have started to see commentary on the way in which the Productivity Commission is being sidelined in important debates. Ross Garnaut in a recent article in the Australian Financial Review, 23 March 2005, called for 'a return to independent, authoritative and transparent analysis of trade policy options as a basis for public education and discussion.' Similarly, Ross Gittins in the Sydney Morning Herald last month, in commenting on the government's proposed inquiry into infrastructure said: 'When the Government is sidelining its independent inquiry agency it is a sign they do not want good economic policy getting in the way of expedient politics.' ${ }^{\prime}$

It is therefore intriguing and encouraging to see the Productivity Commission challenging the Howard government's approach to economic reform. As Alan Wood, in the Australian of 15 April 2005 made clear, 'the Productivity Commission's final report on National Competition Policy makes plain ... success will depend on co-operative federalism.' Wood concluded that the Prime Minister has rejected the Productivity Commission's advice on the need to co-operate with the states because it does not suit his new aggressive centralist agenda. The key issue here is not whether the Prime Minister, the Productivity Commission or Alan Wood will prove to be correct. What this incident illustrates is the valuable role of authoritative and independent commentary and analysis in the ongoing task of building the case for genuine economic reform.

As an indicator of the role of informed debate in building the basis for such reforms, the Productivity Commission pointed to some of the lessons to be learnt from National Competition Policy including:

- 'That such an ambitious program received support from all governments can be attributed to much pre-existing evidence of the potential gains from reform, to broad agreement on the means of achieving those gains and to effective political leadership.'

- 'Independent and transparent review and assessment processes are critical to secure good outcomes, especially on contentious issues; prevent backsliding; and promote public understanding of the justification for reform.'

- 'In any reform program, the potential adjustment and distributional implications should be considered at the outset, with decisions about transitional assistance guided by appropriate principles. $^{2}$

The argument for independent analysis and advice to government across a range of issues has been gathering momentum. My colleague, Lindsay Tanner, has called for the creation of a national infrastructure commission. He said, 'Australia 
has been well served by bodies like the Grants Commission, Australian Competition and Consumer Commission, Reserve Bank, Australian Bureau of Statistics and the Productivity Commission. The role of such expert, non-partisan bodies in economic policy is steadily increasing. Although in many cases, the ultimate decisions properly remain in the hands of elected governments, such bodies play a vital filtering role and provide benchmarks against which the actions and promises of governments can be measured.' (Renewing Australia's Infrastructure, Speech to Australian Council for Infrastructure Development, 21 March 2005). I believe that it is time that we created an independent agency to play this role so that we might enhance the quality of debate in Australia about fiscal policy

Wanna, Kelly and Forster in their book, Managing Public Expenditure in Australia, described accountable budgetary processes as 'a key mechanism of stable democratic societies' (200: 1). With the increasing focus on the state and appropriateness of fiscal policy, I would argue we need the public to be able to make informed judgements. The importance of budgets to a society is that budgets 'have long quantified the possibilities open to government' (Wanna et al 12). Therefore, knowledge about the true state of the budget allows people to express their views about the choices government is contemplating or about the choices presented at election time.

Managing Public Expenditure in Australia is an excellent analysis of how our spending priorities are decided. It is alarming that there is nothing comparable on how much we should spend in the first place. This book also highlights the basis of the allegations made concerning John Howard's cover-up of his $\$ 9$ billion budget deficit before the 1983 election and the equivalent allegations by conservative politicians concerning a similar accusation against the Keating government before the 1996 election.

It is argued that these allegations served as the basis for the Howard government's decision to introduce a Charter of Budget Honesty (1998). This legislation has many virtues. Together with the previous history of budgetary reforms, in particular with regard to the forward estimates, it has provided a reasonable basis for examination of some aspects of current fiscal policy. However a number of problems remain which need to be addressed.

It is widely recognised that the out-year numbers in the forward estimates are unrealistic. That is, future expenditure is understated so that surpluses appear larger. This creates a significant distortion in the analysis of election commitments by governments and oppositions. The Charter of Budget Honesty also has serious shortcomings in so far as it relates to the section concerning election costings.

In fact, the Charter of Budget Honesty, in so far as it relates to the costing of election promises, is as rigged as the Florida voting system. Each appears to have all the trappings of fairness but in practice each is seriously skewed in favour 
of the incumbent. It sounds like something from a George Orwell novel when you suggest that something with as innocent a title as the Charter of Budget Honesty is actually a rigged system designed to favour its founders. But there is no doubt. After three futile attempts to operate under the rules of this Charter it is clear that it is deliberately and demonstrably unfair. This not an accidental by-product of the system or a flaw in its implementation. It is a conscious and deliberate design feature of the system.

The fundamental issue is that the government has access to the bureaucracy in the lead-up to the campaign. Therefore they can have all their policy proposals tested and costed as options for cabinet consideration in advance of the election. This enables an interactive, iterative approach in which options are tested, assessed, modified and determined in a gradual, evolutionary way. The government party can then conveniently retain these options for release during the election.

By contrast, the opposition has a one-off shot with access only to the publicly available information. Three examples from the most recent election should serve to establish the case. Medicare Gold had been costed rigorously with the assistance of health economists, social and economic modelling specialists and actuaries. The departments of Treasury and Finance found no fault with their work. However, in costing the policy the departments used unpublished casemix data. This was never available to the opposition. There was no capacity for the opposition to have access to this data before the policy was publicly announced and its costings released. Had a party in government been seeking to introduce such a policy they would have been able to access this data before their policy was released: an open and shut case of bias in the rules of the game.

Similarly, in the case of the sale of Telstra, the departments were in a position to assist any incumbent government with the task of costing the sale by virtue of the fact that they had available to them confidential dividend information supplied by Telstra. This information was not available to the opposition. What all this makes clear is that although both government and opposition go through the same processes after the election is called, the pre-election circumstances are such that the inevitable outcome is that the government parties are at a massive advantage.

A powerful contemporary example of the shortcomings of the Charter of Budget Honesty as it relates to election costings is the recent events surrounding the government's Medicare safety net. There are two aspects of the problem. One is minor, although of contemporary political relevance, concerning the government's state of knowledge. The other aspect is the failure of the current system to deal with the fundamental flaws in the safety net proposal which are unaffected by the threshold at which it cuts in. First, the timetable. The Howard government knew at the time of the 2004 Budget that the costs for the Medicare 
safety net were blowing out - they provided an extra \$240 million to fill the gap. By June the Health Minister knew that the anticipated annual take-up on which the costing assessment was based had been reached in just three months.

By September, the Pre Election Fiscal Outlook (PEFO) disclosed, under the guise of parameter changes, that the shortcomings in the scheme had led to an approximately 100 per cent increase in the cost of the safety net due to, amongst other things, higher out of pocket costs. This was an inevitable consequence of the perverse incentives built into the system as originally designed. It was only marginally affected by the threshold changes required by the Senate.

It was not until 27 September, just 12 days before the election, that the costings by Finance of Labor's pledge to abolish the safety net revealed the full extent of the blow-out. This revealed that the cost of the scheme had reached $\$ 1.3$ billion over four years. It is inconceivable that the government was not aware of the extent of the blow-out. The Department of Finance would not observe such a phenomenon and fail to advise their minister or the Department of Health. And yet despite the transparency claimed for the Charter of Budget Honesty process, none of it would have been revealed without the coincidence of Labor's pledge to abolish the scheme. Those monitoring the process in the public interest need to be more independent and given an explicit responsibility to make such dangers public as soon as possible.

This logically leads us to the second aspect of the problems of the safety net. Experience has shown what should have been obvious from the start:

- The scheme created perverse incentives which were likely to increase the overall cost of the provision of health services, not reduce it; and

- It was also inevitable, and has proved to be the case, that the greatest benefits of the scheme would flow to the already well-off. The statistics for September 2004 show that the benefits are heavily skewed to high income electorates.

The data published by the Minister for Health shows that of the top 20 constituencies in terms of benefits received from the safety net, 15 also feature in the top 20 electorates by income. The top four, and six of the top seven, are on the North Shore of Sydney. This is a massive subsidy to the North Shore of Sydney from the Western suburbs and regional Australia. For example, the Education Minister Brendon Nelson's seat of Bradfield had received almost \$1 million while the remote seat of Lingiari in the Northern Territory with an approximately 30 per cent Indigenous population had received only $\$ 20,000-$ a ratio of more than 40:1 in favour of the already well-off.

What the political process needs is a process which is more likely to expose these fundamental flaws rather than cover them up.

Ross Gittins, in the Sydney Morning Herald, outlined the fundamental unfairness of this system in an article written soon after the 2004 election. The first, and 
initially unexpected, handicap for current and future oppositions lies in the timing and impact of the pre-election fiscal outlook. Gittins says of this:

In the good old days, once this year's budget (or, occasionally, the mid-year review) was on the table, the parties knew how much they had to play with and could safely get on with deciding and announcing their major policies.

Not any more. Thanks to the advent of the PEFO, the Opposition cannot be certain how much it has to spend until 10 days into a (usually) five-week campaign. (The Treasurer has the advantage of being able to seek continuous informal indications from his underlings.) ...

So here we have the advent of the PEFO acting to damage rather than enhance the democratic process. Labor - and all subsequent oppositions - will have to find a way of releasing its policies in broad terms early, then firming up the specifics during the campaign.

On the central issue of the imbalance of advice Gittins summarises the situation as follows:

Finally we come to the farcical operation of the provision for Treasury and Finance to cost the two parties' promises during the campaign. It is a farce because it is so heavily weighted against the Opposition - any opposition.

The trouble is, the bureaucrats are the servants of the Government for almost 35 months out of every 36. Only during the election campaign's 'caretaker period' are they given their independence and permitted to treat both sides equally.

So the Government gets all the access it wants to the bureaucrats' expertise until just the last few weeks. And in the run-up to each election, it peppers them with hundreds of requests for the costing of hypothetical policies.

What's more, the Government's pre-election contact with the bureaucrats is an 'iterative' (trial-and-error) process: how much would it cost if we decided to do A? If you wanted to do A it would cost $\mathrm{X}$, but if you did Al, which isn't very different, it would cost only Y. Oh, really. Thanks for the tip.

Trouble is, the bureaucrats aren't permitted to give such helpful advice to the Opposition - not during the term, nor during the caretaker period. The Opposition just submits its policy costings and waits for the bureaucrats' public pronouncement. Any working papers or background information the Opposition supplies to the bureaucrats must be made public - and thus perused by their political opponents. 
You see now just how unbalanced the process is. The Government is largely feeding back to the bureaucrats their own costings, whereas the Opposition runs a high risk of slipping up somehow and being monstered by the Treasurer. ${ }^{3}$

None of this should lead to a conclusion that the process of rigorous costing of election policies is illegitimate. It is simply the case that the existing rules and processes are inherently unfair. In my experience the officials from Treasury and Finance do an honest and thorough job within the rules as they stand. But nothing they can do overcomes the fact that the process is rigged against the opposition, whichever party that may be from time to time.

We also need to repair some gaping holes in the fiscal policy debate. While both major parties claim they believe in balancing the budget over the economic cycle neither has been prepared to recognise the logical outcome of this position. This has led to the absurd position where leaders of both parties have committed to potentially counter-productive pro-cyclical measures.

For example, the Prime Minister, John Howard in 2003 put forward what was a superficially attractive proposition: 'our principle is that if you have paid off your debt ... and you have a surplus, you have no right to keep more than the surplus you need. And we therefore take the view that when ... you've met your priority areas of spending like defence and health and so forth, you should then give what is over back to the people who own it - that is the Australian taxpayers'. 4

However Simes, in analysing this proposition, pointed out its fundamental absurdity as a policy prescription:

The logic of this approach to policy is that tax cuts will be provided at times when revenues are buoyant - that is, in economic booms - and the Budget will be tightened when weaker economic conditions hurt revenues - precisely the opposite of good policy. ${ }^{5}$

However, this is a problem which has had bipartisan dimensions.

After the recent elections, and therefore outside the pressure of an election period, the previous Leader of the Opposition said in a speech in Parliament, 'we will not run budget deficits' without any qualification to recognise that economic circumstances will certainly change over the next five years. ${ }^{6}$

Now, these two gentlemen are not stupid or economically illiterate. So, why do they propose what they must know could be counterproductive? It is because in public life in Australia today it is not acceptable to mention the dreaded ' $\mathrm{D}$ ' word, deficit!

Everybody knows, and simple arithmetic makes clear, that balancing the budget over the economic cycle means being prepared to run deficits when the economy 
is running at below average levels of activity. It also means that merely being in surplus may not be sufficient during times of very strong growth. What is needed is something like the structural deficit analysis undertaken by Access Economics and the OECD. Access Economics defines the structural budget cash balance as one which 'separates cyclical (factors) from long term fundamentals ... that is, it estimates where the Budget would be if the economy were running at trend levels of activity.' In effect, it is the measure which allows us to check whether we are meeting our target of balancing the budget over the economic cycle.

For example, their latest Budget Monitor concludes:

... both 2004-05 and 2005-06 are expected to see the most notable deterioration in the structural integrity of the Budget since, well, the last election. By the latter year the structural Budget may have returned to deficit, the victim of overly enthusiastic policy decisions in the six months from April to October $2004 .^{7}$

They also compare the structural balance with the Intergenerational Report as follows:

Remember that 'the structural Budget balance' abstracts from the bump and grind of the economic cycle. The Intergenerational Report (IGR) did that too. And remember that 'the structural Budget balance' is estimated assuming current policies are maintained - again, exactly as the IGR did. Therefore the IGR results (and the 40 year average they imply - a Federal primary deficit of 1.4 per cent of GDP) are effectively a measure of the long run structural Budget balance. The IGR itself therefore said that, judged on a 40 year benchmark (rather than the 4 year benchmark used in the Access Economics analysis here), today's Budget policies imply an average long term structural Budget deficit of 1.4 per cent of GDP, or over $\$ 11$ billion a year in today's money. ${ }^{8}$

The OECD also produces a structural balance assessment of the Australian budget as well as those of other member countries. While the two are not strictly comparable due to minor methodological differences and because the OECD works on a calendar year basis while Access uses a financial year basis, they produce sufficiently similar assessments to give confidence in the accuracy of the work.

The Access Economics Budget Monitor makes a significant contribution to such intelligent discussion of fiscal policy and the budget as there is at the moment in Australia. If it were to be reinforced by a higher profile agency which might work with Access to enhance the Monitor generally, and the structural balance analysis in particular, it would make an even greater contribution to public knowledge of national fiscal policy. 
The fundamental proposition about balancing the budget also has its critics. Economist Fred Argy proposes that we should run a small deficit over the cycle. Argy contends: 'that governments should balance revenue against recurrent expenditures ... over the economic cycle ... However, at present their fiscal targets go well beyond that ... (their) target requires that revenue be used to finance capital expenditure as well as recurrent expenditure over the long term This is fiscal conservatism gone mad (Fred Argy, Where To From Here?, p 155). Conversely, Ric Simes has argued that we should run a small surplus over the cycle. ${ }^{9}$

An accurate and informed debate about all these issues is a very important part of a healthy democracy. Therefore, I believe a new institutional framework to facilitate and inform fiscal policy debate in Australia is necessary.

There are essentially two precedents that we could follow. In the United States, clear, formal bureaucratic structures are enhanced by the Congressional Budget Office and the Council of Economic Advisers. It is hard to see how the Congressional Budget Office model could be made to work in the Westminster system. The Parliamentary Research Service already does an outstanding job and I do not believe that the Congressional Budget Office model is the way forward.

There is considerable merit in adding to our economic policy infrastructure a council of economic advisers. With the strength of independent economic analysis and think tanks and private financial institutions as well as the universities we have a very useful and powerful tool of old economic advice to the government. I have had the opportunity to discuss the concept of an Australian Council of Economic Advisers with people with knowledge of the US model such as Professor McKibbin here at the ANU. Any Australian council would be similar to but different from the US model. There are many business, academic and institutional economists who would willingly provide their services to advise the Prime Minister, or the Treasurer, about a broad range of important economic issues.

The days when the information, the technology and the resources were exclusively available to government to analyse such issues are long gone. In fact, bank economists with access to up-to-date data on lending, deposit and financial transaction are better placed to advise on some issues than public sector economists. Regular reports, analysis and commentary from such a council would improve the overall quality of economic debate while also broadening the base of economic advice to the government of the day.

However, I regard this as a much broader initiative than merely dealing with the questions of fiscal policy to which I am referring to her. The more interesting precedent is the British Institute of Fiscal Studies, an independent body which comments on and promotes research and informed discussion of fiscal matters. 
Some examples of its ongoing work which are relevant to the 2005 UK general election are:

- monthly bulletins analysing the Government's public finance figures;

- analysis of 2005 budget and spending review options;

- examination of the evolution of the level of taxation as a share of national income;

- briefing notes on long-term trends in British taxation and spending;

- assessment of the distributional impact of policies;

- ongoing analysis of trends in inequality;

- analysis of the impact of the three parties' higher education funding policies; and

- detailed assessment of the Conservative Party's proposal to increase support for pensioner saving.

Ric Simes outlined his views of the case for an Australian equivalent of the Institute of Fiscal Studies in the following terms:

The involvement of the ABS can help to enhance the integrity of the basic data. This is a starting point. However, a greater challenge is to sustain a high level of public debate on public policy issues to promote better decisions. Australia has managed to stimulate such debate on specific issues at different times. For example, the tariff reform and labour market policies have benefited from the extensive research and policy efforts both within the public sector (e.g. the Productivity Commission and its precursors) and the universities.

On the other hand, the level of debate over macroeconomic policy issues more generally has varied over time. A large proportion of Australia's better macroeconomists are housed within the Reserve Bank, but much of the serious debate on monetary policy stays within the building. It would be healthier all round if a means could be found to strengthen the research capability on monetary policy outside of the Reserve Bank thereby enabling a more robust public debate.

Similarly, the level of public debate on fiscal policy would benefit greatly from more consistent high-level research and review. This would provide invaluable input in what at times is a quite superficial reporting on these matters. In turn, Government decision-making would be improved.

A modest amount of strategic funding would allow Government to establish an independent centre - with a proposed title of the Institute for Fiscal Affairs (IFA) - and with a brief to monitor and analyse policy. The location of the Institute could be determined via a tender. University departments and private consulting firms with existing expertise in related areas may be attracted to bid for the project' ${ }^{10}$ 
I believe this is a compelling case. A potential work program for an Institute of Fiscal Studies could include:

- costing and analysis of government and opposition policies;

- regular analysis of the implications of government monthly financial statements;

- analysis of state government budgets and opposition proposals (if states join the scheme);

- $\quad$ similar work on New Zealand if New Zealand joins the scheme;

- further development of the structural analysis of the budget balance

- a review of the Charter of Budget Honesty;

- monitoring the performance of fiscal policy against the government's fiscal rules and principles;

- conducting research into policies related to intergenerational matters; and

- promoting public debate on fiscal policy.

The key question remaining is: how should such an institute be funded to enable it to operate strongly while remaining independent? The following models recommend themselves:

a. a model based on the Australian Strategic Policy Institute - that is, a budget funded model as a free standing institute gaining its reputation for quality and independence from the standing of the original director and subsequently from the rigour and relevance of the output;

b. an exclusively private sector funding model similar to the various think tanks in the United States;

c. a government funded body with an independent board;

d. a government funded body with a charter of legislative independence;

e. an independent body funded as a result of a government tender for independent services of this kind;

f. a body similar to one of those listed above, owned by more than one government, for example, one that all is also funded by one or more state governments, and possibly also by the New Zealand government; and,

g. a specialist sub-part of the Productivity Commission.

It seems to me that the best outcome is likely to be achieved by a combination of e. (an independent body) and f. (a body that is similar to those above and owned by more than one government).

The advantages of a transparently independent body to perform functions of the type outlined here are its real and apparent neutrality and the freedom it obtains from public service constraints. If some or all of the states and New Zealand were interested in participating this would add the benefit that no one income source could 'own' the institute. 
Such an institute could also contribute to Geoff Mulgan's outline of one of the issues for governments to consider in rebuilding trust. He said, 'Other issues for government include independent performance information and more accessibility. In an information-intensive environment where the public is full of experts, good trustworthy government operates in open ways that make use of society's intelligence.' $^{11}$

Through such a process it is likely that an independent consortium such as a university combining with an independent economic assessment firm might well win the tender for a period of three to five years at a cost of not much more than $\$ 1$ million per year to the taxpayers. Of course, it will be obvious to some that this model bears some similarities to the Australian and New Zealand School of Government structure, but then again, imitation is the sincerest form of flattery. If such an independent agency were to be established it could also take over the election costing functions currently performed by Treasury and Finance under the Charter of Budget Honesty Act.

The essential thesis I am putting forward is this: Australia's economic performance needs re-invigoration. Such a process has many aspects. My emphasis tonight is on the need to establish the basis for an enhanced and informed debate about economic policy generally and fiscal policy in particular. This is vital to ensure that as we proceed through the $21^{\text {st }}$ century we do so on the basis of a fiscal policy targeted to our long-term economic needs, which optimises the utilisation of taxpayers' funds and which enables a fair and informed assessment of alternative proposals put forward during the course of our democratic dialogue, particularly at election time.

An independent Institute of Fiscal Studies based in Australia or Australia and New Zealand would make a significant contribution to this and enhance our chances of avoiding the complacency and relative failure of the first decades of the 20th century. We cannot afford that complacency now.

\section{Bibliography}

Access Economics (2004) Budget Monitor, October.

Argy, Fred (2003) Where To From Here?, Australia, Allen \& Unwin.

Baehler, Karen; Callister, Paul; Gregory, Bob; Hawke, Gary; Ladley, Andrew; Ryan, Bill; Scott, Claudia; Stephens, Bob; Walker, Ann; Wolf, Amanda (2005) 'Surveying Research on New Zealand Government: What Next?', ANZSOG Research Survey, Australian Journal of Public Administration, March.

Garnaut, Ross (2005) 'Blend trade talks into bigger picture', Australian Financial Review, 23 March.

Gittins, Ross (2005) Sydney Morning Herald, 21 March. 
Gittins, Ross (2004) 'Charter of Budget Honesty distorts election campaigns', Sydney Morning Herald, 18 October.

Holden, John (2004) Capturing Cultural Value, Demos.

Horne, Donald (1964) The Lucky Country, Penguin.

Kay, John (2004) The Truth about Markets, Penguin

Latham, Mark (2004) Hansard, 17 November.

Mitchell, Alan (2005) 'Transparency pays its way', Australian Financial Review, 23 March.

Mulgan, Geoff (2004) Mulgan Comments on Trust, ANZSOG News, Spring.

Organisation for Economic Cooperation and Development (2005) OECD Economic Surveys 2004 Australia, February.

Ormerod, Paul (1997) Butterfly Economics, New York, Pantheon Books.

Productivity Commission (2005) Review of NCP Reforms.

Simes, Ric (2003) Fiscal Policy Rules in Australia, Chifley Research Centre, September.

Tanner, Lindsay (2005) 'Renewing Australia's Infrastructure', Speech to Australian Council for Infrastructure Development, 21 March.

Tiffen, Rodney \& Gittins, Ross (2004) How Australia Compares, Cambridge University Press.

Wanna, John, Kelly, Joanne and John Forster (2000) Managing Public Expenditure in Australia, St Leonards, Allen \& Unwin.

Warhurst, John (1982) Jobs or Dogma, St Lucia, University of Queensland Press. Wood, Alan (2005) Australian, 15 April.

\section{ENDNOTES}

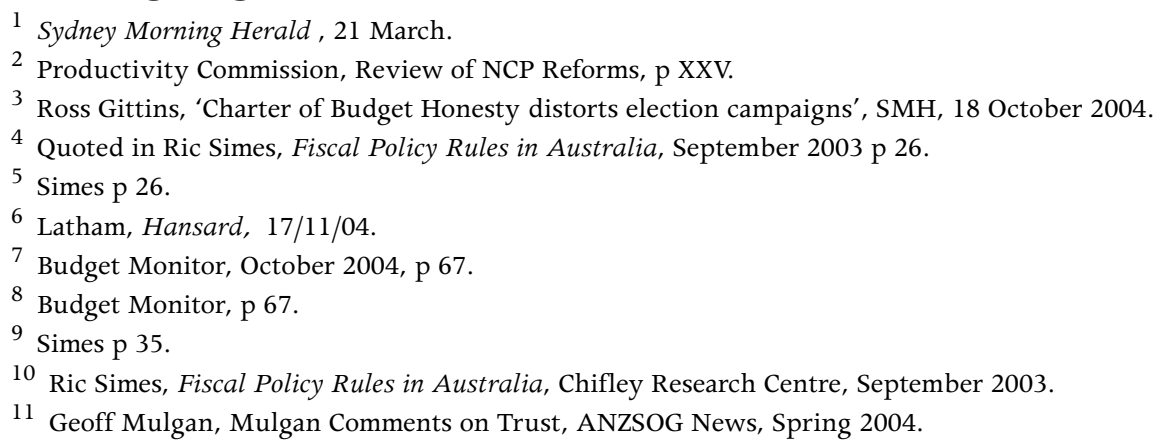

